\title{
ATMIRUŠĀS KOKSNES DAUDZVEIDĪBA DAŽĀDOS MEŽOS ZEMGALĒ
}

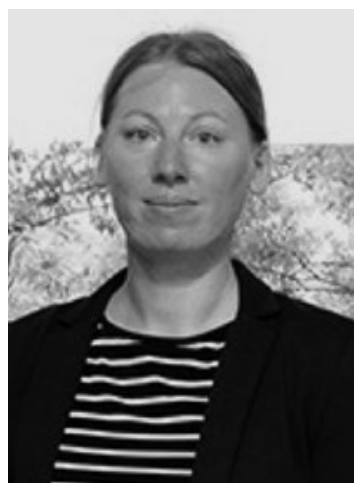

Līga Liepa ir ieguvusi maǵistra un doktora grādu Latvijas Lauksaimniecības universitātes (LLU) Meža fakultātē. Pašreiz turpat strādā par pēcdoktorantūras vadošo pētnieci un docenti, specializējusies meža ekologijā. Galvenie pētniecības virzieni ir bioloğiskās daudzveidības un ekosistēmu pakalpojumu novērtēšana meža ekosistēmās, kā arī interesē starpdisciplināru pieeju lietojums socioekoloǵiskos pētījumos.

Raksturvārdi: boreonemorālie meži, kokaudzes struktūrelementi, substrāta pieejamība, saimnieciski meži, dabas aizsardzības rīki, biologiskā daudzveidība.

\section{Ievads}

Pēdējos gados būtiski pieaugusi un arvien aktuālāka kḷuvusi atmirušās koksnes nozīme biologiskās daudzveidības saglabāšanā. Turklāt vēsturiski, īpaši ziemeḷu puslodes meža ekosistēmās, cilvēks nesen atmirušu koku vai tā daḷas ir izmantojis par kurināmā resursu, lai tiktu apmierinātas primārās eksistenciālās vajadzības, ieskaitot nodrošinājumu ar siltumu un pārtiku. Līdz ar to interese par atmirušās koksnes pieejamību un tās sniegtajiem pakalpojumu veidiem ir bijusi aktuāla dažādām mērkgrupām jau gadsimtiem ilgi. Tāpat ir atrasta sakarība starp atmirušās koksnes daudzumu un apdzīvojumu, proti, meža ekosistēmās vairāk daudzveidīgu atmirušās koksnes struktūrelementu ir sastopami tālāk no apdzīvotām vietām. Zināms, ka atmirusī koksne noder par substrātu daudzām organismu grupām, kuras tieši vai netieši ir atkarīgas no tās. Piem., boreālā bioma meža ekosistēmās ar atmirušo koksni saista vairāk nekā 7000 taksonu $^{1}$, bet nemorālos mežos - 4500. Savukārt Latvijā vairāk nekā 90 retu un aizsargājamu

\footnotetext{
${ }^{1}$ Stokland et al. 2012.
}

sugu eksistence tieši un netieši ir saistāma ar atmirušās koksnes substrātu un tā pieejamību².

Kopumā atmirušās koksnes substrāts ir mainīgs elements. Tā daudzveidību raksturo kokauga suga, diametrs, garums, sadalǐšanās pakāpe, telpiskais novietojums, apgaismojums, kā arī citi apstākḷi. Tāpat izšķir šādus atsevišskus veidus: sausoknis - stāvošs sauss koks, stumbenis - stāvošs koka stumbrs vai tā daḷas un kritalas - gulošs sauss kritis koks vai tā daḷas. Koksnes sadalīšanās procesā izmainās ķīmiskās un fiziskās īpašības, kas vēlāk rada atšķirīgu substrāta pieejamību sugām ${ }^{3}$. Kritalām sadaloties, tās kolonizē ķērpju sugas, tad sūnu sugas, ko vēlāk nomaina vaskulārie augi - pirmie kolonizētāji ir zemie lakstaugi, tos nomaina augstie lakstaugi un krūmi, bet vēlāk uz substrāta attīstās kokaugi. Piem., parastās egles kritalas pēdējās sadalīšanās pakāpēs nodrošina substrāta pieejamību jaunu kokaugu sēklu attīstībai, tādējādi izvairoties no konkurences ar vaskulārajiem augiem zemsedzē $\overline{ }^{4}$. Sugu daudzveidība sūnaugiem uz

\footnotetext{
2 Liepa et al. 2019.

3 Zimmerman et al. 1995.

4 Sollins et al. 1982.
} 
kritalām mainās līdz ar sadalī̌̌anās pakāpēm un tādiem elementiem kā miza, koksnes tekstūra un attālums līdz augsnei. Piem., atmirušās koksnes sadalīšanās ātrums no pirmās līdz piektajai pakāpei ir atkarīgs no koka sugas, un tas var aizn,emt no 10 gadiem (piem., parastai apsei Populus tremula) un vidēji no $45 \mathrm{lid}$ z 75 gadiem, atseviškłos gadijumos pat 100 gadus (parastai eglei Picea abies) ${ }^{5}$. Vairāki pētījumi apliecina, ka lielāks sugu skaits ir saistīts ar lielu dimensiju atmirušo koksni ${ }^{6}$. Tas ir skaidrojams ar to, ka lielāks sugu skaits spēj kolonizēt substrātu ilgākā periodā, salīdzinot ar mazu dimensiju atmirušo koksni. Savukārt mazu dimensiju atmirusī koksne sugām var būt īslaicīga patvēruma vieta, sugām izplatoties un pārvietojoties meža ainavā. Atsevišķu sugu sastopamība ir saistīta ar atmirušās koksnes novietojumu, piem., saulainu un sausu vietu pieejamība nodrošina labvēlīgus apstākḷus dažādiem bezmugurkaulniekiem, savukārt ēnas un paaugstināta mitruma tuvumā atmirušās koksnes substrātu var apdzīvot epiksilas sugas. Tāpat sugu daudzveidība tieši ir atkarīga no kokauga sugas.

Interese par atmirušās koksnes substrāta pieejamību saimniecisko mežu platībās parādỉjusies līdz ar intensivas apsaimniekošanas pasākumu praktizēšanu. Pastāv vairāki apgalvojumi, kur norādīts, ka intensīvi apsaimniekotos mežos atmirušās koksnes daudzums un daudzveidība ir nepietiekama, lai nodrošinātu pastāvīgu vai pagaidu dzìvotni ar to saistītām sugām.

Atsevišķos pētijjumos norādīts, kādas ir minimālās atsauces vērtības, proti, cik daudz atmirušās koksnes ir nepieciešams, lai tiktu nodrošināta ar šo substrātu saistītu sugu eksistence, un tas ir no $20 \mathrm{līdz} 50 \mathrm{~m}^{3} / \mathrm{ha}^{-1}$ dažādos mežos ${ }^{7}$. Savukārt šīs vērtības ir minētas kā ieteicamās, un to iegūšanai izmantots modelēšanas paṇēmiens. Atsevišksos avotos norādīts, ka kritiskā sliekšṇa vērtība ir $15 \mathrm{~m}^{3} / \mathrm{ha}^{-1}$. Nesen veiktā pētījumā par atmirušās koksnes pieejamību Eiropas mežos noskaidrots, ka vidēji tā ir $15,8 \mathrm{~m}^{3} / \mathrm{ha}^{-1}$, bet Latvijas mežos $-26,4 \mathrm{~m}^{3} / \mathrm{ha}^{-1}{ }^{8}$

\footnotetext{
5 Stokland 2001.

6 Kruys et al. 2002; Stokland, Larsson 2011.

7 Müller, Bütler 2010.

8 Puletti et al. 2019.
}

Svarīgi ir apzināt atmirušās koksnes daudzumu dažādos saimnieciskos mežos un teritorijās ārpus tām, lai varētu iegūt vidējās vērtības un izvērtēt šì substrāta pietiekamību. Papildus tam nepieciešams noteikt, cik bieži ir sastopamas sugas, kas saistītas ar šo substrātu, un vai pastāv saistība starp substrāta pieejamību un atsevišku organisma grupu, indikatorsugu un speciālo biotopu sugu sastopamību. Šāda pieeja l̦auj novērtēt pēc empīriskiem datiem noteiktās atmirušās koksnes minimālās kritiskā sliekšņa vērtības (proti - cik daudz ir pietiekami?), tāpat novērtēt, vai lielāks daudzums atmirušās koksnes nodrošina lielāku sugu skaitu un daudzveidību (proti - vai vairāk ir vairāk?), kā arī noteikt, vai atseviškso sugu sastopamība ir saistīta tikai ar atmirušās koksnes substrāta pieejamibu.

Pētỉjuma mērkisis ir noskaidrot atmirušās koksnes substrāta pieejamību īpaši aizsargājamos meža biotopos saimniecisko mežu platībās. Novērtējumā izmantoti autores vairāku gadu veiktie empīriskie pètījumi dažādos mežos Zemgalē.

\section{Materiāls un metodes}

Pētījums veikts Zemgales regionā, kur kopumā izvēlētas 54 mežaudzes skujkoku mežos (dominē parastā priede Pinus sylvestris L. un parastā egle Picea abies (L.) H. Karst.), platlapju mežos (dominē parastais osis Fraxinus excelsior L.) un staignāju mežos (dominē melnalksnis Alnus glutinosa (L.) Gaertn.). Visi pētījuma objekti ierīkoti aizsargājamos meža biotopos, kas saimniecisko mežu platībās funkcionē kā "biologiskās daudzveidības karstie punkti” kopš pagājušā gadsimta 90. gadiem. Izvēlēto audžu vidējā platība ir 2,5 ha. Visas pētījumā iekḷautās audzes ir pieaugušas un pāraugušas. To vidējais vecums ir no 85 gadiem staignāju mežos un vairāk par 160 gadiem skujkoku mežos. Kopumā katrā pētījuma mežaudzē tika ierīkots viens pastāvīgs parauglaukums $20 \times 50 \mathrm{~m}$ platībā, kur mērīti kokaudzes struktūrelementi, ietverot atmirušās koksnes noteikšanu. Katrā parauglaukumā tika uzmērīti sausokṇi, stumbeṇi un kritalas. Uzmērītajai atmirušajai koksnei vai to dạ̄ām (sausokṇiem, stumbeṇiem un kritalām) noteiktas arī atmirušās koksnes sadalī̌sanās 


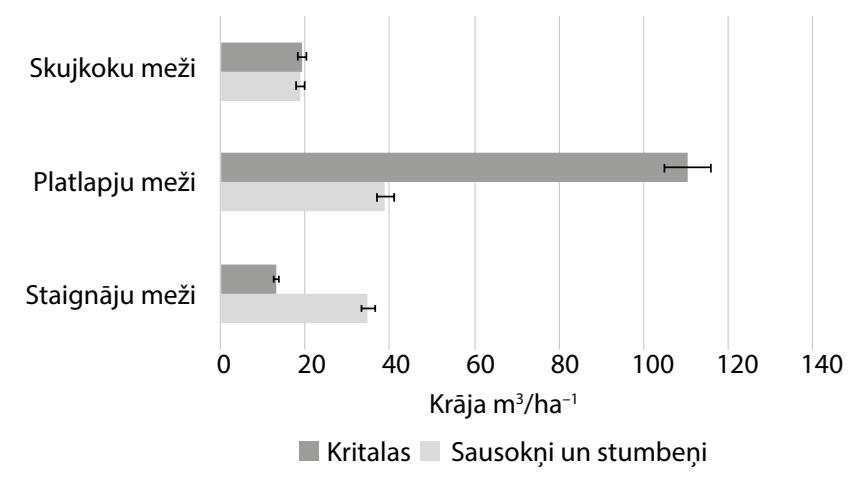

1. attēls. Kopējais atmirušās koksnes sadalījums staignāju, platlapju un skujkoku aizsargājamos meža biotopos Zemgalē (Liepa et al. 2019)

pakāpes ${ }^{9}$. Atmirušās koksnes sadalīšanās pakāpes iedala šādi: I - koks nesen atmiris, tā miza ir neskarta un koksnes krāsa saglabājusies sākotnējā; II - stumbra forma apaļa, zaudēti daži mizas gabali, koksne saglabājusies cieta un krāsa - sākotnējā; III - koksne ir nedaudz mīksta, mizas klājums ir mazāks par 50\%, sākotnējā krāsa nav mainījusies; IV - koksne ir mīksta, miza izzudusi, koksnes struktūru veido mazi un irdeni gabali; V - stumbra daļas ir izzudušas, atlikušās dal̦as deformējušās un iegrimušas augsnē, koksne ir l̦oti mīksta, un to veido mazi un irstoši gabali, koksne var būt klāta ar augiem. Iegūtie dati apkopoti un apstrādāti, un rezultāti ir interpretēti.

\section{Rezultāti un diskusija}

Kopumā noskaidrots, ka atmirušās koksnes substrāta vislielākā pieejamība sastopama platlapju mežos - vidēji 149,5 m³/ha-1. Tāpat augsti kvantitatīvie rādītāji ir staignāju mežos, kur atmirušās koksne vidējā vērtība ir $48,0 \mathrm{~m}^{3} / \mathrm{ha}^{-1}$ (1. attēls). Sausokṇu un stumbeņu īpatsvars staignāju mežos ir $72 \%$, skujkoku mežos - 38\%, bet platlapju mežos - $12 \%$. Pastāv pieñēmums, ka optimāla substrāta pieejamỉbu daudzām organismu grupām nodrošina aptuveni $50 \%$ stāvošu un 50\% gulošu atmirušu koku vai to daļas. Iegūtie aprēḳini liecina, ka šāds ippatsvara sadalijums sastopams skujkoku

\footnotetext{
9 Stokland 2001.
}

mežos, kur sausokņi un stumbeņi veido $49,5 \%$, bet kritalas - 50,5\% (1. attēls). Samērā augsti kritalu apjoma rādītāji platlapju mežos ir saistīti ar patogēno organismu izplatību regionā ${ }^{10}$. Zināms, ka pārauguša vecuma audzēs un dabiskos mežos koku atmiršana saistìta ar koka biologisko vecumu. Tiem pamazām palēninās metabolisma procesi un samazinās ikgadējais koksnes pieaugums, kā arī paaugstinās uzñēmība pret patogēnorganismiem un vides apstākḷu maiṇu ${ }^{11}$. Savukārt staignāju mežos vērojama pašizrobošanās dinamiska attīstība, kur stāvošu atmirušu koku lielāko īpatsvaru veido parastā egle.

Koka atmiršanu izraisa vairāki procesi un faktori - gan audzes iekšienē (piem., mitruma izmaiņas), gan ārienē (dabiskie). Audzes noturību ietekmē dažādi traucējumi, piem., vējgāzes, vējlauzes, snieglauzes un snieggāzes ${ }^{12}$. Koku bojāeju var izraisīt arī izteikti mainīgi vides apstākḷi, piem., sals, sausums, temperatūras svārstības, mitruma daudzums u. c., ${ }^{13}$ vai konkurence. Atmirušās koksnes kvantitatīvo vērtību novērtējumā bieži lietots sadalījums pa dimensijām. Visos pētītajos mežos visvairāk sastopami mazu dimensiju sausokṇi un stumbeñi (2. attēls). Savukārt skujkoku mežos lielāko ìpatsvaru veido vidēju dimensiju atmirusī koksne $(49,2 \%)$, bet lielu dimensiju atmirusī

\footnotetext{
10 Matisone et al. 2018.

11 Kramer, Kozlowski 1979.

12 Kuuluvainen 1994.

13 Franklin et al. 1987.
} 


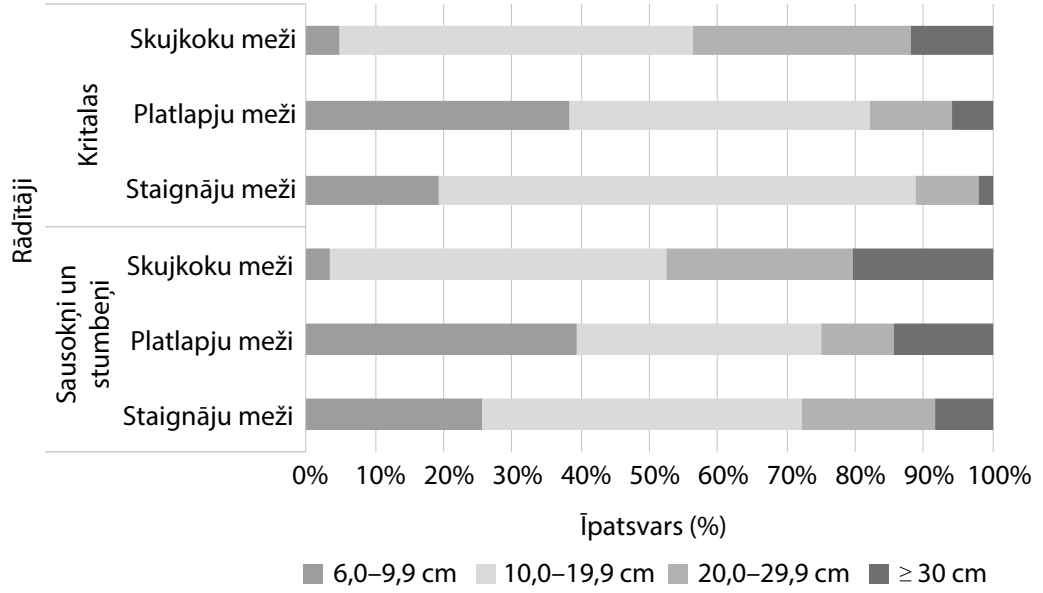

2. attēls. Kopējais atmirušās koksnes sadalījuma īpatsvars pa dimensijām staignāju, platlapju un skujkoku aizsargājamos meža biotopos Zemgalē (Liepa et al. 2019)

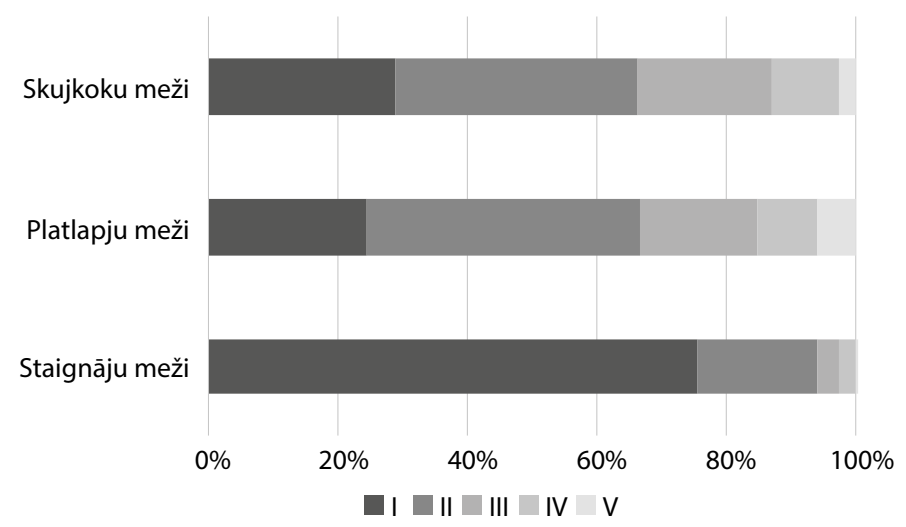

3. attēls. Kopējais atmirušās koksnes sadalījuma īpatsvars pa sadalī̌anās pakāpēm staignāju, platlapju un skujkoku aizsargājamos meža biotopos Zemgalē

koksne veido $20,3 \%$, platlapju mežos - 14,3\% un staignājos $-8,2 \%$ (2. attēls). Mazu dimensiju atmirušās koksnes pārstāvniecība ir skaidrojama ar konkurenci. Savukārt vidēju un lielu dimensiju atmirusī koksne nodrošina stabilu mitruma līmeṇa un temperatūras saglabāšanos, tādējādi koksnes sadalī̌sanās process notiek lēnāk un atmirusī koksne nodrošina stabilu substrāta pieejamību daudzām organismu grupām $^{14}$. Vairāki pētījumi apliecina, ka lielāks sugu skaits ir saistīts ar lielu dimensiju atmirušo koksni ${ }^{15}$.

Tomēr lielākai sugu daudzveidībai ir nepieciešams lielu dimensiju atmirušās koksnes substrāts, jo tas nodrošina vairāk pieejamo nišu, stabilākus mikroklimatiskos apstākḷus un dzīvotnes pieejamību ilgākā periodā. Lìdz ar to dabas aizsardzībā nereti lielu dimensiju atmirušās koksnes substrāts tiek vērtēts augstāk, salīdzinot ar vidēju un mazu dimensiju

\footnotetext{
14 Stokland et al. 2012.
} 
atmirušās koksnes pieejamību. Pretēji - citā pētijumā minēts, ka epiksilo sūnu sugu skaits staignāju mežos Latvijā nav saistīts ar lielu dimensiju kritalām ${ }^{16}$.

Atmirušās koksnes kvalitatīvo vērtību noteikšanai bieži vien tiek vērtētas pieejamā substrāta sadalī̌anās pakāpes, jo tās nodrošina kontinuitāti meža ekosistēmās. Sadalī̌̌anās process var ilgt no vairākiem gadiem līdz vairākām desmitgadēm. Tas ir atkarīgs no koka sugas.

Vērtējot sadalī̌̌anās pakāpju dinamiku, tika konstatēts, ka vislielāko ìpatsvaru veido pirmā un otrā sadalǐšanās pakāpe (3. attēls). Noskaidrots, ka I sadalīšanās pakāpes atmirusī koksne visvairāk sastopama staignāju mežos - 87\%, platlapju mežos - 54\% un skujkoku mežos - 42\% (3. attēls). Tas liecina par samērā nesen atmirušiem kokiem vai to dal̦ām. Jāuzsver, ka, piem., tipiskos staignāju mežos lielākā daļa kritalu ir daḷeji vai pilnīgi iegrimušas ūdenī un sadalī̌sanās process šādos apstākḷos norit lēnāk, jo lielākā daḷa kritalu atrodas bezskābekḷa vidē zem ūdens ${ }^{17}$. Savukārt skujkokiem koksnes ķīmiskās īpašības nodrošina samērā ilgstošu sadalīšanās procesu, kur pat vienas sadalīšanās pakāpes pārstāvniecība var ilgt lïdz desmitgadei.

16 Madžule, Brūmelis 2008.

17 Liepa, Straupe 2016.

\section{Secinājumi}

Kopumā noskaidrots, ka dažādos aizsargājamos meža biotopos sastopamas daudzveidīgas atmirušās koksnes kvantitātes un kvalitātes. Tāpat veiktais pētijums liecina par to, ka samērā liels daudzums atmirušās koksnes var nodrošināt pietiekamu substrāta pieejamību ar to saistītām organismu grupām. Noskaidrots, ka lielāko īpatsvaru veido atmirusī koksne dažādos mežos Zemgalē un ka atmirusī koksne ir sākotnējās (I un II) sadalīšanās pakāpēs. Tas var būt saistīts ar apsaimniekošanas pasākumu praktizēšanu blakus audzēs, kur abiotisko faktoru ietekmes rezultātā aizsargājamos meža biotopos pieaug kritalu daudzums. Tāpat jāuzsver, ka liela dą̧a šo mežu ir pārsnieguši koku bioloğisko vecumu. Nepieciešami tālāki pētījumi, lai noskaidrotu, vai atbilstošs daudzums un atmirušās koksnes pieejamība var ietekmēt ar substrātu saistìto sugu sastopamību, jo specifisko sugu klātesamība var būt saistīta ar sugas bioǵeogrāfisko izplatību, dabisko un antropogēno traucējumu biežumu un intensitāti, kā arī ar abiotisko un biotisko faktoru mijiedarbību.

Šì pētniecības aktivitāte īstenota projekta Ekologisko interešu lìdzsvarošana pieaugošas dabas resursu izmantošanas kontekstā saimnieciskos mežos (Nr.1.1.1.2/VIAA/2/18/294) 1.1.1.2. pasākumā Pēcdoktorantūras pētniecības atbalsts. Projektu līdzfinansē Eiropas Reğionālās attīstības fonds.

\section{VĒRES}

Franklin, J. F; Shugart, H. H.; Harmon, M. E. (1987) Tree death as an ecological process. BioScience, 37, 8, 550- 556.

Kramer, P. J.; Kozlowski, T. T. (1979) Physiology of woody plants. New York : Academic Press.

Kruys, N.; Jonsson, B. G.; Ståhl, G. (2002) A stage-based matrix model for decay-class dynamics of woody debris. Ecological Applications, 12, 3, 773-781.

Kuuluvainen, T. (1994) Gap disturbance, ground microtopography, and the regeneration dynamics of boreal coniferous forests in Finland: a review. Annales Zoologici Fennici, 31, 1, 35-51.

Liepa, L.; Straupe, I. (2016) Edge influence on stand structural characteristics in unmanaged black alder swamp woods in Southern Latvia. Surveying Geology \& Mining Ecology Management, 409-414.

Liepa, L.; Straupe, I.; Miezìte, O.; Jansons, Ā. (2019) Structural diversity of dead wood in small-scaled protected forest parcels in Latvia. Research for Rural Development, 1, 12-17.

Madžule, L.; Brūmelis, G. (2008) Ecology of epixylic bryophytes in Eurosiberian alder swamps of Latvia. Acta Universitatis Latviensis, Biology, 745, 103-114.

Madžule, L.; Brūmelis, G.; Tjarve, D. (2012) Structures determining bryophyte species richness in a managed forest landscape in boreo-nemoral Europe. Biodiversity and Conservation, 21, 2, 437-450. 
Matisone, I.; Matisons, R.; Laiviņš, M.; Gaitnieks, T. (2018) Statistics of ash dieback in Latvia. Silva Fennica, $52,1,6$.

Müller, J.; Bütler, R. 2010. A review of habitat thresholds for dead wood: a baseline for management recommendations in European forests. European Journal of Forest Research, 129, 6, 981-992.

Puletti, N.; Canullo, R.; Mattioli, W.; Gawryś, R.; Corona, P.; Czerepko, J. 2019. A dataset of forest volume deadwood estimates for Europe. Annals of Forest Science, 76, 3, 68.

Sollins, P. (1982) Input and decay of coarse woody debris in coniferous stands in western Oregon and Washington. Canadian Journal of Forest Research, 12, 1, 18-28.

Stokland, J. N. (2001) The coarse woody debris profile: an archive of recent forest history and an important biodiversity indicator. Ecological Bulletins, 71-83.

Stokland, J. N.; Larsson, K. H. (2011) Legacies from natural forest dynamics: Different effects of forest management on wood-inhabiting fungi in pine and spruce forests. Forest Ecology and Management, $261,11,1707-1721$.

Stokland, J. N.; Siitonen, J.; Jonsson, B. G. (2012) Biodiversity in Dead Wood. New York : Cambridge University Press.

Zimmerman, J. K.; Pulliam, W. M.; Lodge, D. J.; Quinones-Orfila, V.; Fetcher, N.; Guzman-Grajales, S.; Parrotta, J. A.; Asbury, C. E.; Walker, L. R.; Waide, R. B. (1995) Nitrogen immobilization by decomposing woody debris and the recovery of tropical wet forest from hurricane damage. Oikos, 772, 3, 314-322. 